
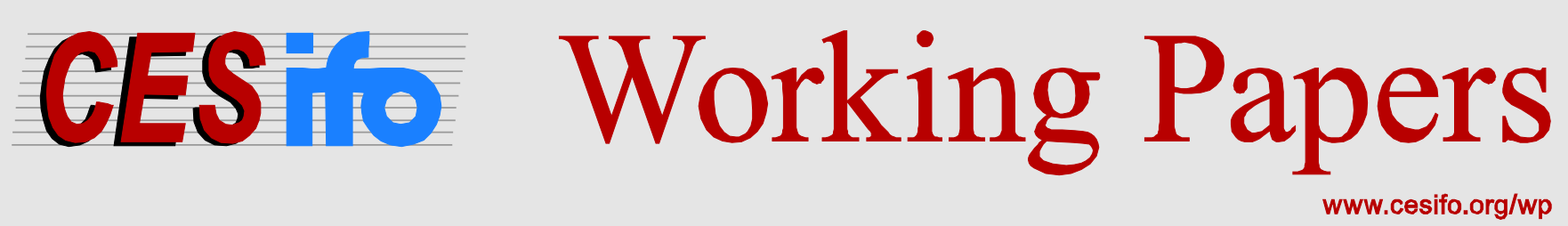

\title{
Reference Income Effects in the Determination of Equivalence Scales Using Income Satisfaction Data
}

\author{
Melanie Borah \\ Andreas Knabe \\ Carina Kuhställer
}

CESIFO WORKING PAPER NO. 6123

CATEgory 3: SOCIAL PROTECTION

OCTOBER 2016

An electronic version of the paper may be downloaded

- from the SSRN website: Www.SSRN.com

- from the RePEc website: Www.RePEc.org

- from the CESifo website: www.CESifo-group.org/wp 


\title{
Reference Income Effects in the Determination of Equivalence Scales Using Income Satisfaction Data
}

\begin{abstract}
We estimate household equivalence scales using income satisfaction data from the German Socio-Economic Panel. We extend previous studies applying this approach by taking reference income into account. This allows separating needs-based from reference effects in the determination of income satisfaction. We show that this adjustment helps to overcome a bias causing an overestimation of adults' and an underestimation of children's needs-based equivalence weights. Our results indicate that controlling for income comparisons eliminates the gap between equivalence scale parameters for adults and children found in other studies.
\end{abstract}

JEL-Codes: I320, J130, D310.

Keywords: equivalence scale, income satisfaction, relative income.

\author{
Melanie Borah \\ Otto von Guericke University \\ Faculty of Economics \& Management \\ P.O. Box 4120 \\ Germany - 39016 Magdeburg \\ Melanie.Borah@ovgu.de
}

Andreas Knabe

Otto von Guericke University

Faculty of Economics \& Management

P.O. Box 4120

Germany - 39016 Magdeburg

Andreas.Knabe@ovgu.de
Carina Kuhställer

Otto von Guericke University

Faculty of Economics \& Management

P.O. Box 4120

Germany - 39016 Magdeburg

Carina.Kuhstaeller@ovgu.de 


\section{Introduction}

Equivalence scales reflect the differences in the expenditures of households of different sizes and composition, when all these households "attain the same level of utility or standard of living” (Lewbel and Pendakur, 2008). They are applied to make household incomes comparable whenever the welfare derived from income is of greater interest than the absolute level of income, e.g., in income inequality and poverty analyses as well as in the design of redistributive policies. Today, a variety of equivalence scales are in use, although the debate continues which of these scales captures best how a household's needs change when persons join or leave the household.

It is possible to distinguish three approaches to determine equivalence scales. Each method has its strengths, but also some fundamental shortcomings, which we will discuss only very briefly here (for further discussions, see Bradbury, 1989, Coulter et al., 1992, and van Praag and Warnaar, 1997). The first approach is to let experts assess the needs of households with different structures (expert scales). This can, for example, be done by compiling baskets of goods which are supposed to allow households of different composition to enjoy the same standard of living. The OECD scale (OECD, 2005) is the best-known example of an expert scale. The main shortcoming of expert scales is that they are based entirely on rather arbitrary judgments and generally lack a consistent theoretical or empirical foundation. The second approach is to empirically estimate equivalence scales from objective data, e.g. by using the share of expenditure on particular goods to proxy welfare (Deaton and Muellbauer, 1986) or estimating a system of demands (McClements, 1977). These scales are often derived from sophisticated theoretical models and are based on empirical evidence. However, as noted, among others, by Pollak and Wales (1979), they suffer from identification problems and rely heavily on the assumptions of the underlying model. The third approach uses subjective data and relies on survey responses to questions asking for subjective evaluations, either of own household income or of how much income would be needed to reach a particular level of welfare (for an overview, see Bradbury 1989). These methods also build on empirical evidence but rely on a different set of assumptions, most importantly that people correctly evaluate their "welfare” or "standard of living” when assigning verbal labels to their actual or hypothetical levels of income (see e.g. van Praag and van der Sar, 1988). 
In recent years, the subjective method has received increasing attention. For example, Schwarze (2003), van Praag and Ferrer-i-Carbonell (2004) and Biewen and Juhasz (2015) all use data on self-reported satisfaction with household income from the German SocioEconomic Panel to analyze how income satisfaction depends on actual household income as well as household size and/or structure and to determine an equivalence scale by calculating the income compensation necessary to hold satisfaction constant as family size/structure changes. These studies generally find high economies of scale compared to commonly used expert scales. In particular, children are assigned much lower equivalence weights than those found in expert scales or real-world welfare systems. Schwarze (2003), for example, finds that a second child requires an increase in household income of less than 10 percent of the income needs of a single adult, whereas a second adult receives a weight of around 30 percent.

Many previous studies using the subjective method assume that income satisfaction is a valid proxy for the extent to which household members are able to satisfy their needs. However, income satisfaction could also be influenced by a variety of effects, which may not be seen as relevant for genuine needs satisfaction. These influences should not impact the equivalence scale if it is to be applied to inequality and poverty analyses or to inform social policymaking. Bradbury (1989) argues that social comparisons constitute such a factor. It has been convincingly shown that comparisons with other people are of utmost importance when evaluating one's income satisfaction (Clark et al., 2008). In this paper, we take up this argument and show that the low weights previous studies have assigned to children can be explained by reference income effects. We suggest a modification of the standard methodology which filters out these effects in the estimation of equivalence scales and closes the gap in the equivalence weights of adults and children.

We propose to perceive satisfaction with household income as an aggregate of "needs satisfaction”, i.e. the satisfaction with one's absolute level of income because it enables consumption of goods and services, and of "status satisfaction”, i.e. the satisfaction with how one's income compares to a reference group. We show that when one determines the monetary compensation necessary to hold income satisfaction constant as family size changes, one obtains the amount necessary to offset the weighted average effect on needs and status satisfaction. When one is interested in compensating needs satisfaction alone, one has to take the distinction between these two subdimensions of income satisfaction into account and control for relative income effects. Whether this increases or decreases estimated equivalence weights depends on whether the income adjustment necessary to keep needs 
satisfaction constant as an additional person enters the household is above or below this additional person's impact on the household's reference income. If children increase reference income by less than they increase the household's needs, the equivalence weights assigned to children in previous studies tend to underestimate the purely needs-based equivalence weights. Using data from the German Socio-Economic Panel (SOEP), we demonstrate the importance of this effect empirically. Our results indicate that the difference in equivalence weights assigned to adults and children generally disappears once we take relative income effects into account. Reference group effects are important and equivalence scale parameters change in the predicted direction in all specifications.

The paper is structured as follows. In the next section, we briefly review the related literature. In Section 3, we present the econometric model used in the estimation of equivalence scales and discuss the bias resulting from the omission of reference group effects. Section 4 introduces the dataset and Section 5 provides descriptive statistics. In Section 6, we describe the construction of reference income. Our main empirical analysis as well as extensions and robustness checks are presented in Section 7. Section 8 concludes.

\section{Related Literature}

In this section, we briefly review the two strands of the literature we combine in our analysis. We first discuss studies using the subjective approach to estimate equivalence scales which take differences between adults and children into account. Then, we briefly review the literature on reference effects in the determination of subjective well-being.

\section{The subjective approach to estimating equivalence scales}

Equivalence scales can be estimated using either objective (e.g. demand) or subjective data. Subjective data include, e.g., people's satisfaction with their own income, and evaluations of hypothetical alternative situations as well as the income people think would be needed to obtain a particular level of welfare for their own or hypothetical families (for a review, see Bradbury, 1989). For example, the “income evaluation question” (IEQ), introduced by Van Praag (1971), asks respondents to state the different income amounts they would need to regard their net household income as "very good”, ..., "sufficient”, ..., or "very bad”. Van Praag and van der Sar (1988) review studies that use the IEQ to estimate equivalence scales and show that it is not necessary to assume cardinality of utility within this framework. A 
closely related concept is the "minimum income question" that asks respondents about the "smallest income they would need to make ends meet each month" (Goedhart et al., 1977). As Melenberg and van Soest (1996) have pointed out, the problem with these two questions is that respondents have to evaluate hypothetical situations. Since most of them are not, and might never have been, in a situation where they can just "make ends meet” or where their actual incomes correspond to the IEQ's extreme answers "very good” or "very low", it is difficult for them to answer these questions consistently. ${ }^{1}$

To overcome this problem, more recent studies have used questions that ask people to report their satisfaction with their actual household income and to reply on a pre-defined scale. A key assumption is that individuals evaluate their equivalent income when answering the satisfaction question, rather than the absolute level of income (Schwarze, 2003). Melenberg and van Soest (1996) show that using income satisfaction data leads to substantially lower estimated economies of scale, and thus higher equivalence weights, than using the IEQ. Charlier (2002) demonstrates that estimates using income satisfaction data yield results that are fairly close to the modified OECD scale, whereas if data on satisfaction with life in general is used, the estimated equivalence weights appear to be very low.

The income satisfaction approach has been used to estimate equivalence scales that differentiate between adults and children. Schwarze (2003) uses data from the SOEP to estimate an equivalence scale of the form $S^{e}$, where $S$ is the household size and $e$ is the equivalence elasticity (Buhmann et al., 1988). He extends this approach by allowing the equivalence elasticity to depend on the number of children in the household and finds that children receive a lower weight than additional adults. While the first additional adult in a (former) one-person household receives a weight of 34\% of the first adult, the first child of a single (couple) is given a weight of only 30 (17) percent of the first adult and the second child has a weight of 14 (8) percent. Overall, Van Praag and Ferrer-i-Carbonell (2004) find qualitatively similar results, with lower weights when using the German SOEP and higher weights when using the British Household Panel Study (BHPS).

Biewen and Juhasz (2015) propose using nonlinear techniques to estimate more flexible specifications of equivalence scales. Using income satisfaction data from the SOEP, they also find that the first additional adult is given more weight than children (26\% for an additional

\footnotetext{
${ }^{1}$ Steiger et al. (1997) conduct a qualitative study with cognitive interviews to illustrate the difficulties people have when answering the minimum income question.
} 
adult and 11\% for each child in the OECD-type specification). Bollinger et al. (2012), using BHPS data, find large economies of scale in the core (married or cohabiting) couple but much smaller economies of scale, or even diseconomies of scale, for children and additional adults. The key explanation for this finding is that it is conceivable that goods, in particular housing, cannot be shared to the same degree outside the core couple as within. In addition, there might be some child-specific goods, which are not shared with adults and may be outgrown rapidly. Furthermore, the authors find that the costs of children vary with age, suggesting a U-shaped pattern, with 8-12 year olds being associated with the lowest additional costs. Charlier (2002) and Melenberg and Van Soest (1996) also estimate higher weights for children at the age of 12 than at the age of 6. On the contrary, Rojas (2007), using Mexican data, finds that younger children receive larger weights than teenagers.

Table 1 summarizes the equivalence weights estimated in studies that explicitly differentiate between adults and children. In most specifications, the weight assigned to children depends on the total number of household members. We report the necessary income increase for two relevant cases, namely for the first child in a one- and a two-adult household. Most studies, especially those using recent panel data from developed countries, have in common that they find smaller equivalence weights for adults and children than those assigned by commonly used expert scales (OECD scale, square root scale). Strikingly, children generally receive substantially smaller equivalence weights than adults (where the findings by Bollinger et al. (2012) are a notable exception).

\section{Reference Income}

There is overwhelming evidence that people's subjective well-being depends, inter alia, on how their income compares to some benchmark (for an overview, see Clark et al., 2008). This benchmark, or "income aspirations”, are formed based on own past income (habituation) and the income of comparable others (social comparison). Stutzer (2004) shows empirically that income aspirations are affected through both channels and that the negative effect of higher aspirations on satisfaction with life is of a similar magnitude as the positive effect of own income, suggesting that a proportional change in both leaves well-being unchanged. 
Table 1: Overview of estimated equivalence weights of adults and children

\begin{tabular}{|c|c|c|c|c|c|}
\hline \multirow[b]{2}{*}{ Scale/Author } & \multirow[b]{2}{*}{$\begin{array}{l}\text { Specification / } \\
\text { Subsample }\end{array}$} & \multirow[b]{2}{*}{ Data } & \multicolumn{3}{|c|}{$\begin{array}{l}\text { Weight given to the additional household } \\
\text { member (1st adult }=1 \text { ) }\end{array}$} \\
\hline & & & 2nd adult & $\begin{array}{c}\text { 1st child } \\
\text { (in } 2 \text { adult/ } \\
1 \text { adult } \\
\text { household) }\end{array}$ & $\begin{array}{l}\text { 2nd child } \\
\text { (in } 2 \text { adult/ } \\
1 \text { adult } \\
\text { household) }\end{array}$ \\
\hline \multicolumn{6}{|l|}{ Expert Scales } \\
\hline OECD & & & 0.50 & 0.3 & 0.3 \\
\hline Square root & & & 0.41 & $0.32 / 0.41$ & $0.27 / 0.32$ \\
\hline \multicolumn{6}{|l|}{ Subjective Approach } \\
\hline \multirow[t]{2}{*}{ Schwarze (2003) } & Pooled sample & SOEP & 0.34 & $0.17 / 0.30$ & $0.08 / 0.14$ \\
\hline & Fixed effects & & 0.28 & $0.13 / 0.24$ & $0.06 / 0.11$ \\
\hline \multirow[t]{2}{*}{ Bollinger (2012) } & Men & BHPS & 0.15 & $1.12 / 1.64$ & $0.68 / 1.22$ \\
\hline & Women & & 0.31 & $1.17 / 1.52$ & $0.41 / 0.78$ \\
\hline \multirow[t]{2}{*}{ Rojas (2007) } & Child (<12) & Mexican & 0.39 & $0.41 / 0.53$ & $0.33 / 0.38$ \\
\hline & Teenager (12-18) & ENIGH & 0.39 & $0.24 / 0.32$ & $0.21 / 0.25$ \\
\hline Biewen \& Juhasz (2015) & OECD-type & SOEP & 0.29 & 0.11 & 0.11 \\
\hline \multirow{2}{*}{$\begin{array}{l}\text { Van Praag \& Ferrer-i- } \\
\text { Carbonell (2004) }\end{array}$} & & SOEP & 0.23 & $0.16 / 0.13$ & $0.10 / 0.08$ \\
\hline & & BHPS & 0.37 & $0.23 / 0.17$ & $0.15 / 0.11$ \\
\hline $\begin{array}{l}\text { Melenberg \& van Soest } \\
(1996)^{*}\end{array}$ & & $\begin{array}{l}\text { Dutch } \\
\text { Soc.-Ec. } \\
\text { Panel }\end{array}$ & 0.88 & $0.76 /$ na & 0.61/na \\
\hline Charlier (2002)* & & SOEP & 0.43 & $0.28 / 0.36$ & $0.15 / 0.17$ \\
\hline
\end{tabular}

* Equivalence weights reflect the case that the first child is 12 years old and the second child is 6 years old.

Notes: To ease the comparison of the various studies, we converted results such that they can be consistently interpreted as the equivalence weights relative to the first adult.

There is, however, no consensus on the exact composition of the reference group or how to best construct reference income. A few studies have empirically examined the composition of relevant reference groups. Clark and Senik (2010) explicitly analyze who is in the reference group using data from the European Social Survey. When having to evaluate their satisfaction with their own labor income, most respondents report that they compare themselves more to colleagues than to, e.g., family members or friends. Goerke and Pannenberg (2015), using data from a pretest module of the SOEP where respondents report how important various reference groups are for them as well as how they perceive their income relative to these reference groups, find that the most important reference groups are colleagues at the 
workplace, other people in the same occupation and friends. Furthermore, the respondents' life satisfaction depends on how they perceive their income in comparison to the income of these reference groups. However, absolute income always remains important too. Since both studies focus on individual labor income, it remains unclear, however, to what extent these insights transfer to satisfaction with household income.

If the specific composition of the reference group and actually perceived relative income positions are unknown, reference incomes have to be estimated. Clark et al. (2008) argue that a natural candidate for the reference income is the income of "people like me" which may be calculated as a group average of people with similar observable characteristics (e.g. Ferrer-iCarbonell, 2005) or using a Mincer earnings equation in which a similar set of characteristics is used to predict incomes of observationally similar individuals (e.g. Clark and Oswald, 1996 and Senik, 2008).

Ferrer-i-Carbonell (2005) investigates the impact of "comparison household income" on individual well-being. Her results, based on data from the SOEP, suggest that the average income of the reference group is equally important as own household income in determining life satisfaction. The reference group consists of individuals with a similar education, age and region of residence. Furthermore, Ferrer-i-Carbonell (2005) provides empirical support for an asymmetric reference effect. While people feel worse if they fall below average, they do not gain much from higher incomes if they already have an above-average income.

In addition to the reference income, as defined so far, the income rank of the individual within the reference group may play an important role in the determination of satisfaction (Clark et al., 2009). Boyce et al. (2010) explicitly differentiate between the reference-income hypothesis and the rank-income hypothesis. Using BHPS data, their evidence suggests that the income rank is more important than both absolute and reference income.

While most studies examine reference group effects in the determination of life satisfaction, job satisfaction or satisfaction with individual labor income, the few studies that specifically address household-level comparisons (e.g. Clark, 2009, Senik, 2008) also indicate that income comparisons matter for income or economic satisfaction at the household level. Thus, it seems reasonable to examine reference group effects also when using data on satisfaction with household income. 


\section{Econometric Model}

In this section, we present the econometric model used in our analysis. We first describe the subjective approach to derive equivalence scales directly from income satisfaction data. Then we discuss the role of relative income intuitively and develop a formal model that accounts for its effects explicitly.

\subsection{Direct estimation of equivalence scales}

To illustrate the subjective approach to estimate equivalence scales, let us assume that income satisfaction is determined by:

$$
S_{i t}=\alpha+\beta_{1} f\left(\frac{Y_{i t}}{\operatorname{HHeq}\left(a_{i t}, k_{i t}\right)}\right)+X_{i t}^{\prime} \theta+\varepsilon_{i t}
$$

where $S_{i t}$ is income satisfaction reported by household $i$ at time $t, Y_{i t}$ is household income, HHeq is the household's total equivalence weight (as a function of household size and composition, i.e. of the number of adults $a_{i t}$ and children $k_{i t}$ ), $X_{i t}^{\prime}$ is a vector of other personal and household characteristics, and $\varepsilon_{i t}$ is an i.i.d. error term. The function $f($. allows for nonlinearities in the relationship between equivalent income and income satisfaction (e.g. due to diminishing marginal satisfaction with income). To estimate this model, we have to make explicit assumptions about the functional form of HHeq. In the following, we will use two commonly used functional forms: a constant-elasticity scale and a fixed-weights scale.

\section{Linear Model (constant-elasticity scale)}

A commonly used scale assumes that household size affects a household's total equivalence weight with a constant elasticity (see Buhmann et al., 1988):

$$
\operatorname{HHeq}\left(a_{i t}, k_{i t}\right)=\left(a_{i t}+k_{i t}\right)^{e} \text {. }
$$

In its most simple form, there is no distinction between adults and children, such that $a_{i t}$ and $k_{i t}$ enter with equal weights. $e$ is the equivalence scale elasticity with respect to household size. The well-known square-root scale is a special case, with $e=1 / 2$. 
This functional form was used by Schwarze (2003) to estimate the equivalence elasticity from income satisfaction data. Its advantage is that it allows rewriting equation (0) as a linear regression equation if we assume that the relationship between equivalent income and income satisfaction is logarithmic, i.e. $f(x)=\ln x$. Equation (0) can then be written as

$$
\begin{aligned}
S_{i t} & =\alpha+\beta_{1} \ln \left(\frac{Y_{i t}}{\left(a_{i t}+k_{i t}\right)^{e}}\right)+X_{i t}{ }^{\prime} \theta+\varepsilon_{i t} \\
& =\alpha+\beta_{1} \ln Y_{i t}-\beta_{1} e \ln \left(a_{i t}+k_{i t}\right)+X_{i t}{ }^{\prime} \theta+\varepsilon_{i t}
\end{aligned}
$$

The equivalence scale elasticity $e$ can subsequently be calculated by dividing the estimated regression coefficients on $\ln \left(a_{i t}+k_{i t}\right)$ and $\ln Y_{i t}$, i.e. $e=\beta_{1} e / \beta_{1}$.

Schwarze (2003) also proposes a modification of (0) that differentiates between adults and children in the estimation of the equivalence scale elasticity. He assumes that the equivalence scale elasticity depends linearly on the number of children: $e=e_{a}-b k_{i t}$. In this specification, $e_{a}$ is the equivalence scale elasticity of a household consisting of adults only. A positive (negative) $b$ reflects that households with children have a lower (higher) equivalence scale elasticity than an adults-only household with an equal number of members.

The advantage of modelling the equivalence weight differences between adults and children via a linear adjustment of the scale elasticity is that the regression equation can, again, be written in linear form:

$$
\begin{aligned}
S_{i t} & =\alpha+\beta_{1} \ln \left(\frac{Y_{i t}}{\left(a_{i t}+k_{i t}\right)^{e_{a}-b k_{i t}}}\right)+X_{i t}{ }^{\prime} \theta+\varepsilon_{i t} \\
& =\alpha+\beta_{1} \ln Y_{i t}-\beta_{1} e_{a} \ln \left(a_{i t}+k_{i t}\right)+\beta_{1} b k_{i t} \ln \left(a_{i t}+k_{i t}\right)+X_{i t}{ }^{\prime} \theta+\varepsilon_{i t}
\end{aligned}
$$

As in (0), the parameters of interest, i.e. the equivalence elasticity for a household without children, $e_{a}$, as well as the adjustment parameter when children are present, $b$, can be calculated by dividing the respective regression coefficients: $e_{a}=\beta_{1} e_{a} / \beta_{1}$ and $b=\beta_{1} b / \beta_{1}$.

\section{Nonlinear Model (fixed-weights scale)}

Another commonly used scale is the fixed-weights scale, of which the OECD scale is the best-known example (OECD, 2005). Fixed-weights scales assume that a household's equivalence weight is linear in the number of additional adults and children: 


$$
\operatorname{HHeq}\left(a_{i t}, k_{i t}\right)=1+\delta_{a}\left(a_{i t}-1\right)+\delta_{k} k_{i t} .
$$

$\delta_{a}$ and $\delta_{k}$ directly represent the equivalence weights of additional adults and children, respectively, relative to the first adult in the household. The (modified) OECD scale sets $\delta_{a}=.5$ and $\delta_{k}=.3$.

Assuming a logarithmic relationship between equivalence income and income satisfaction, the corresponding regression model can be written as

$$
S_{i t}=\alpha+\beta_{1} \ln \left(\frac{Y_{i t}}{1+\delta_{a}\left(a_{i t}-1\right)+\delta_{k} k_{i t}}\right)+X_{i t}^{\prime} \theta+\varepsilon_{i t}
$$

Since the parameters $\delta_{a}$ and $\delta_{k}$ enter nonlinearly, equation (0) has to be estimated using nonlinear estimation techniques. We apply nonlinear OLS (using Stata’s $\mathrm{nl}$ command).

\subsection{The role of relative income: an intuitive approach}

Suppose that satisfaction with household income depends both on the absolute level of consumption, i.e. the extent to which household members are able to satisfy their personal needs and wants ("needs satisfaction”), as well as on how the family's household income compares to that of a relevant reference group ("status satisfaction”). For example, income satisfaction could be constructed as a weighted average of needs satisfaction and status satisfaction. When examining households of different sizes, the change in household income necessary to keep income satisfaction constant would then have to compensate for changes in needs as well as status satisfaction. The estimated equivalence scale would thus represent the hypothetical compensation for (an average of) both effects. If we are only interested in the income adjustment necessary to keep the household's needs satisfaction constant when an additional member joins the household, we would obtain biased estimates if the extent to which this person affects the household's reference income deviates from this person's additional needs.

This bias can go in either direction. When an additional person joins a household, this household's reference group may change. It might be the case that the difference between the new and the old reference group's average household income exceeds the amount by which this person increases the consumption needs of the household. In this case, the equivalence weight obtained by (0) is an overestimate of the person's purely needs-based equivalence 
weight. The reverse case is also conceivable, where an additional household member's needs exceed the change in reference income. In this case, the person's needs-based equivalence weight will be underestimated.

To illustrate how the differential effects on a household's needs and reference income might affect the estimation of needs-based equivalence weights of adults and children, let us consider the following two hypothetical examples:

1. Consider a single person who is now forming a household with a partner. The absolute needs of the household increase. To the extent that there are gains from shared consumption, the income required to satisfy needs will not double, though. Suppose it increases by $60 \%$. Assume further that the new reference group consists of two-adult households, for which the reference income is twice as large. Depending on how the individual weighs needs and status satisfaction, income satisfaction will be kept constant only if household income increases by something between $60 \%$ and $100 \%$. This income adjustment would overcompensate needs satisfaction and undercompensate status satisfaction, but exactly compensate their weighted average.

2. Consider the case of a couple deciding to have a child. Suppose that the child increases the household's needs also by $60 \%$ (of the first adult's needs). The household's reference income might increase because comparable households receive government child benefits etc., but it might also decrease, for example because in households with children, the secondary earner tends to work fewer hours. Let us assume that the total effect on the household's reference income is an increase of $10 \%$. To keep income satisfaction constant, an income compensation of something between $10 \%$ and $60 \%$ is needed. In this case, needs satisfaction is undercompensated, but status satisfaction is overcompensated.

As these two cases illustrate, the direction of the bias depends on whether an individual's contribution to a household's needs is above or below her contribution to the household's reference income.

\subsection{The role of relative income: formal analysis}

Formalizing the intuition laid out in the preceding subsection, we extend model (0) by assuming that income satisfaction depends additively on the household's equivalent income 
(transformed by a function $f($.$) - "needs satisfaction") and on relative income Y_{i t} / Y_{i t}^{\text {ref }}$ (transformed by a function $g($.$) - "status satisfaction"), where Y_{i t}^{\text {ref }}$ denotes the household's reference income:

$$
S_{i t}=\alpha+\beta_{1} f\left(\frac{Y_{i t}}{\operatorname{HHeq}\left(a_{i t}, k_{i t}\right)}\right)+\beta_{2} g\left(\frac{Y_{i t}}{Y_{i t}^{r e f}}\right)+X_{i t}^{\prime} \theta+\varepsilon_{i t}
$$

Whether the estimates of the equivalence weights of adults and children are biased, and the direction of this bias, depends on the determinants of reference income. We want to illustrate the bias for the linear model. ${ }^{2}$ As before, we assume that $f($.$) and g($.$) are both$ logarithmic functions.

For the linear model, let us assume that relative income is constructed using the same functional form as the household equivalence weight, but with potentially different parameters. If $Y_{i t}^{r e f}=\omega\left(a_{i t}+k_{i t}\right)^{e_{2}}$, where $e_{2}$ is the household-size elasticity of reference income and $\omega$ denotes the average earnings of the equivalent of the first household member, (0) can be written as:

$$
\begin{aligned}
S_{i t} & =\alpha+\beta_{1} \ln \left(\frac{Y_{i t}}{\left(a_{i t}+k_{i t}\right)^{e_{1}}}\right)+\beta_{2} \ln \left(\frac{Y_{i t}}{\omega\left(a_{i t}+k_{i t}\right)^{e_{2}}}\right)+X_{i t}{ }^{\prime} \theta+\varepsilon_{i t} \\
& =\alpha-\beta_{2} \ln \omega+\left(\beta_{1}+\beta_{2}\right) \ln Y_{i t}-\left(\beta_{1} e_{1}+\beta_{2} e_{2}\right) \ln \left(a_{i t}+k_{i t}\right)+X_{i t}{ }^{\prime} \theta+\varepsilon_{i t}
\end{aligned}
$$

Indicating the parameters estimated in the model without reference income (equation (0)) by a tilde, comparing ( 0$)$ and (0) shows that

$$
\begin{gathered}
\tilde{\alpha}=\alpha-\beta_{2} \ln \omega \\
\tilde{\beta}=\beta_{1}+\beta_{2} . \\
\tilde{\beta}_{1} \tilde{e}=\beta_{1} e_{1}+\beta_{2} e_{2}
\end{gathered}
$$

In particular, the estimated scale elasticity in the model without reference income is a weighted average of the scale elasticities in the needs-based component, $e_{1}$, and that of the reference component, $e_{2}$ :

$$
\tilde{e}=\frac{\beta_{1}}{\beta_{1}+\beta_{2}} e_{1}+\frac{\beta_{2}}{\beta_{1}+\beta_{2}} e_{2} .
$$

\footnotetext{
${ }^{2}$ An analogous formal reasoning applies to the nonlinear model, see Appendix 1.
} 
If the contribution of an additional household member to the household's reference income is larger than the associated increase in the household's needs, i.e. $e_{2}>e_{1}$, ignoring reference effects causes an overestimation of the needs-based scale elasticity in the model without reference income: $\tilde{e}>e_{1}$.

The approach chosen by Schwarze (2003) to incorporate differences between adults and children into the linear model can be extended to the case with reference effects as well. The satisfaction equation is then written as

$$
\begin{gathered}
S_{i t}=\alpha+\beta_{1} \ln \left(\frac{Y_{i t}}{\left(a_{i t}+k_{i t}\right)^{e_{a 1}-b_{1} k_{i t}}}\right)+\beta_{2} \ln \left(\frac{Y_{i t}}{\omega\left(a_{i t}+k_{i t}\right)^{e_{a 2}-b_{2} k_{i t}}}\right)+X_{i t}^{\prime} \theta+\varepsilon_{i t} \\
=\alpha-\beta_{2} \ln \omega+\left(\beta_{1}+\beta_{2}\right) \ln Y_{i t}-\left(\beta_{1} e_{a 1}+\beta_{2} e_{a 2}\right) \ln \left(a_{i t}+k_{i t}\right) \\
+\left(\beta_{1} b_{1}+\beta_{2} b_{2}\right) k_{i t} \ln \left(a_{i t}+k_{i t}\right)+X_{i t}^{\prime} \theta+\varepsilon_{i t}
\end{gathered}
$$

Comparing (0) and (0) shows that the coefficients estimated without reference effects (indicated by tildes) are biased if the scale elasticities differ between household needs and reference incomes:

$$
\tilde{e}_{a}=\frac{\beta_{1}}{\beta_{1}+\beta_{2}} e_{a 1}+\frac{\beta_{2}}{\beta_{1}+\beta_{2}} e_{a 2}, \quad \tilde{b}=\frac{\beta_{1}}{\beta_{1}+\beta_{2}} b_{1}+\frac{\beta_{2}}{\beta_{1}+\beta_{2}} b_{2}
$$

In particular, if additional adults increase reference incomes relatively more than they increase household needs $\left(e_{a 2}>e_{a 1}\right)$, then the purely needs-based weight of additional adults is overestimated in the model without reference effects. Analogously, if the contribution of children to a household's reference income is less than their impact on needs (in the sense that their adjustment factors in the scale elasticities differ, with $b_{2}>b_{1}$ ), the equivalence weight of children will be underestimated.

The estimation of (0) is complicated by the fact that household income and family structure appear in the same way in the needs satisfaction and the status satisfaction components. To separately identify $\beta_{1}$ and $\beta_{2}$ (and thus also all other parameters), we need certain exclusion restrictions (Clark et al., 2008). There have to be exogenous variables that affect income satisfaction only through their impact on reference income, i.e. there must not be a direct effect of these variables on income satisfaction for given levels of reference income. In the empirical part of this paper, we will argue that some personal characteristics, such as the level of education, age (as long as one is of working-age), and gender satisfy this restriction. Even though they certainly affect the composition of people's reference group, and 
thus their reference income, one could reasonably assume that the financial means people require to satisfy their material needs do not differ according to these characteristics. Under this assumption, identification of $(0)$ is feasible.

\section{Data}

We use data from the German Socio-Economic Panel (SOEP), an annual representative panel survey of German private households. ${ }^{3}$ Our analysis covers the years 1984 to 2013. Each year, the SOEP interviews about 20,000 individuals from about 11,000 households who provide information on their objective life circumstances, such as income, employment status, level of education etc., as well as on their subjective evaluations of various life domains, e.g. how satisfied they are with their job, family life, health, personal and household income, and life in general. We restrict the sample to people who are at least 18 years old.

Our dependent variable is income satisfaction. This subjective measure captures individual ordered responses to the question "How satisfied are you with your household income?”, on a scale ranging from zero to ten. Compared to self-reported general life satisfaction, which captures many aspects of life, this measure strongly emphasizes satisfaction of a household's material needs and is therefore more suitable for the assessment of household equivalence scales (Charlier, 2002). Furthermore, there are two questions in the questionnaire asking separately about satisfaction with personal income and satisfaction with household income. This emphasizes that respondents should focus on the household as a whole and not just on their individual situation when evaluating their household income.

Our main explanatory variables are household income and family composition. We use a measure of net monthly household income, obtained from the following question:

"If you look at the total income of all of the members of your household: what is your monthly household income today? Please state the net monthly income, which means after deductions for taxes and social security. Please include regular income such as pensions, housing allowances, child benefits, grants for higher education, maintenance payments, etc.”

\footnotetext{
${ }^{3}$ The data was made available by the German Institute for Economic Research (DIW). A general description of the SOEP is provided by Wagner et al. (2007).
} 
This question provides a quite precise definition of what is meant by net household income, which limits the scope of interpretation available to the respondent and therefore enhances reliability of this variable. To prevent an undue influence of implausibly low and extraordinarily high values of reported household income, we drop the lowest and highest percentile of households in each year's income distribution. To facilitate intertemporal and regional comparability of incomes, we calculate real household incomes (in 2007 euros), using consumer price indices specific to former East and West Germany. The regional differentiation captures persistent price differences between former East and West Germany. We obtain the price indices by combining two datasets. The first dataset, released by the German Federal Institute for Research on Building, Urban Affairs and Spatial Development (BBSR, 2009), contains county-level information on price levels in 2007, which we aggregate to population-weighted averages for East and West Germany. We combine this information with time-series data from the German Statistical Office on changes in consumer prices in East and West Germany to obtain time-series of regional price levels and adjust household incomes accordingly. ${ }^{4}$

The SOEP also contains comprehensive information on a household's composition. We define "children" as all individuals below the age of eighteen in the household, i.e. they do not necessarily have to be biological children of the household head. However, we exclude households where all members are under 18 or where either the household head or his or her partner are minors. This implies a loss of 72 observations. With the SOEP allowing us to identify a respondent's relation to the household head, we are able to restrict our sample further to focus on a very narrow definition of families. We include only one- or two-adulthouseholds with or without minor children in our analysis, where the two adults living within the same households must be partners. We thus ignore all households with adult members besides the household head and his or her partner, e.g. households with grown-up children living in the household. ${ }^{5}$ After applying these sample restrictions, we retain 316,240 observations from 46,976 individual respondents living in 29,381 households.

\footnotetext{
${ }^{4}$ A detailed description on how regional price indices have been constructed is available in Appendix 3. Our main results also hold true when inflation-adjustment is conducted on the basis of a single national consumer price index.

${ }^{5}$ We also conducted analyses with a more broadly defined sample containing also households consisting of more than two adults. Additional adults could be partners, grown-up children, other relatives or non-relatives. The results suggest that the equivalence weights for non-partner adults are considerably higher than those for partners. Our main hypothesis, however, that the relative equivalence weight of children increases when one controls for relative income effects continues to hold.
} 
Other explanatory variables used in this study include age, sex, the level of education (measured as the years of education, derived from personal qualifications), the region of residence (West or East Germany), and labor market status (employed, unemployed, nonparticipating, retired).

\section{Descriptive Statistics}

Table 2 summarizes the share of eight common household types in the total number of households, their mean income satisfaction as well as mean household income. Childless couples indicate the highest average income satisfaction. The presence of children in the household tends to be associated with lower mean income satisfaction both in one- and twoadult households. Nevertheless, couples with children are, on average, more satisfied than single adults without children. Mean household income generally increases in the number of family members (except for the first child in a one-adult household), especially so in the number of adults, but relatively little in the number of children.

Table 2: Mean income satisfaction and household income, by household type

\begin{tabular}{|c|c|c|c|c|}
\hline \multicolumn{2}{|c|}{ Composition of household } & $\begin{array}{c}\text { Percentage share of } \\
\text { household type (in \%) }\end{array}$ & $\begin{array}{l}\text { Mean income } \\
\text { satisfaction }\end{array}$ & $\begin{array}{l}\text { Mean household } \\
\text { income (in euro) }\end{array}$ \\
\hline \multirow{4}{*}{1 adult } & No children & 30.7 & $\begin{array}{c}6.11 \\
(2.47)\end{array}$ & $\begin{array}{c}1390.89 \\
(702.19)\end{array}$ \\
\hline & 1 child & 2.3 & $\begin{array}{l}4.69 \\
(2.57)\end{array}$ & $\begin{array}{c}1364.24 \\
(618.25)\end{array}$ \\
\hline & 2 children & 1.1 & $\begin{array}{l}4.86 \\
(2.48)\end{array}$ & $\begin{array}{l}1581.70 \\
(645.15)\end{array}$ \\
\hline & 3 children & 0.3 & $\begin{array}{l}4.61 \\
(2.68)\end{array}$ & $\begin{array}{c}1808.23 \\
(831.04)\end{array}$ \\
\hline \multirow{4}{*}{2 adults } & No children & 38.3 & $\begin{array}{l}6.64 \\
(2.20)\end{array}$ & $\begin{array}{l}2366.23 \\
(1036.69)\end{array}$ \\
\hline & 1 child & 11.5 & $\begin{array}{l}6.24 \\
(2.25)\end{array}$ & $\begin{array}{c}2525.00 \\
(998.91)\end{array}$ \\
\hline & 2 children & 11.8 & $\begin{array}{l}6.33 \\
(2.16)\end{array}$ & $\begin{array}{l}2719.98 \\
(1005.33)\end{array}$ \\
\hline & 3 children & 3.1 & $\begin{array}{l}6.16 \\
(2.29)\end{array}$ & $\begin{array}{l}2788.51 \\
(1025.60) \\
\end{array}$ \\
\hline \multicolumn{2}{|l|}{ Others } & 1.0 & - & - \\
\hline \multicolumn{2}{|c|}{ No. of observations } & $\begin{array}{c}\text { 197,119 } \\
\text { household-year obs. }\end{array}$ & \multicolumn{2}{|c|}{$\begin{array}{c}\text { 305,976 } \\
\text { individual-year obs. }\end{array}$} \\
\hline
\end{tabular}

Source: SOEP, own calculation, using weights; Note: standard deviation in parentheses.

Table A. 1 in Appendix 2 lists mean values of other explanatory variables used in this study, separated by household type. While there are some significant differences in the average age 
and labor force status of their members, mean education levels are quite similar across household types.

\section{Construction of Reference Incomes}

In the literature on the well-being effects of income comparisons, there are generally two different approaches to construct a person's reference income.

The first approach assumes that individuals compare their household income to the average income of a pre-specified reference group, consisting of people with whom they share a number of important characteristics. This approach has been used by McBride (2001), Ferrer-i-Carbonell (2005) and Stutzer (2004), for instance. In the following, we call this the “cell average approach”. In delimiting the different reference groups, we essentially follow the procedure suggested by Ferrer-i-Carbonell (2005), where reference groups contain individuals of similar age, living in the same region and having a similar level of education. In our study, we distinguish between two regions, East and West Germany, between four education levels ( $<10,11,12,>12$ years of education) and five age groups (under 25, 25-34, 35-44, 45-65, 66 and older). ${ }^{6}$ By constructing reference groups for each year separately, we avoid the problem of people implausibly comparing themselves to people with similar characteristics in earlier or later survey years (see FitzRoy 2014, Mujcic \& Frijters 2015). Following our argument, people evaluate their household income in relation to the average income of other households with a similar composition. ${ }^{7}$ An individual's reference group therefore includes only people who live in similarly structured households. To avoid having too few observations in some reference groups by requiring people to have exactly the same number of children (in addition to being similar in age, region of residence and education), we do not differentiate reference groups on the basis of number of children. Instead, we only distinguish between households according to the number of adults and whether or not there are children in the household. ${ }^{8}$

\footnotetext{
${ }^{6}$ We also analyzed floating age brackets, as proposed by McBride (2001), which gave virtually identical results to fixed age brackets.

${ }^{7}$ Average incomes are determined using the cross-sectional weighting factors provided by the SOEP.

${ }^{8}$ In an attempt to retain sufficiently many observations in each reference group, we do not control for sex in the cell average approach. Including this variable does not seem to change equivalence scale parameters considerably, leaving them to stay in line with our hypothesis, but substantially reduces precision.
} 
The second approach predicts an individual's reference income with a Mincer earnings equation, as in Clark and Oswald (1996) and Senik (2008). While this relies on stronger assumptions about the functional relationship between personal and household characteristics and reference income, it allows including a larger number of determinants of reference income, in particular the number of children. Using OLS, we regress household income on the respondents' age, age squared, sex, the number of years of education, a region dummy, partnership (including the partner's sex), the number of children living in the household, a dummy for being retired and one for being out of the labor force. By not including a separate dummy for unemployment, we assume that the unemployed compare themselves to the employed. We include year dummies to account for year-fixed effects. We refer to this as the “individual Mincer approach”.

A shortcoming of the individual Mincer and the cell average approach is that they do not take into account the characteristics of a respondent's partner. Hence, cell averages and the estimated coefficients in the Mincer approach merge information on households with sometimes very different partner characteristics. Consequently, the estimated reference household incomes for two partnered respondents belonging to the same household may be very different. This problem is alleviated by calculating expected earnings at the household level instead of predicting individuals' earnings separately. To do so, we divide our sample into two subsamples according to the number of adult members and regress household income on the household head's characteristics, as well as his or her partner's information on all control variables in the relevant subsample. We call this extended approach the "household Mincer approach”.

Detailed regression results for both Mincer equations are provided in Table 3. All coefficients carry signs that correspond to economic intuition. In line with our argument, we find the effect of an additional adult on reference income to be much stronger than that of a child in both approaches. Predicted household incomes, corresponding to the reference income of households, are highly correlated across both Mincer specifications and with average incomes of pre-specified reference groups (see Table A. 2 in Appendix 2).

\section{Estimation Results}

We now turn to our empirical results. We analyze how the inclusion of relative income affects the estimated equivalence weights of adults and children first in the linear model and then in 
the nonlinear model. We then conduct robustness checks and examine potential extensions of the model.

Table 3: Detailed regression results for Mincer equations

\begin{tabular}{|c|c|c|c|}
\hline \multirow[t]{2}{*}{ Dependent variable: } & \multicolumn{3}{|c|}{ Real household income } \\
\hline & \multirow{3}{*}{$\begin{array}{c}\text { (1) } \\
\begin{array}{c}\text { Individual Mincer } \\
\text { approach }\end{array}\end{array}$} & $(2)$ & (3) \\
\hline & & \multicolumn{2}{|c|}{ Household Mincer approach } \\
\hline & & Singles & Couples \\
\hline Years of education & $\begin{array}{l}173.42^{* * *} \\
\quad(2.442)\end{array}$ & $\begin{array}{c}114.38 * * * \\
(3.170)\end{array}$ & $\begin{array}{l}132.78^{* * *} \\
(3.527)\end{array}$ \\
\hline Age & $\begin{array}{c}46.01^{* * *} \\
(1.682)\end{array}$ & $\begin{array}{c}28.57 * * * \\
(1.766)\end{array}$ & $\begin{array}{c}27.34 * * * \\
(4.702)\end{array}$ \\
\hline Age squared & $\begin{array}{c}-0.35 * * * \\
(0.018)\end{array}$ & $\begin{array}{c}-0.18 * * * \\
(0.018)\end{array}$ & $\begin{array}{l}-0.19 * * * \\
(0.048)\end{array}$ \\
\hline East & $\begin{array}{c}-465.84 * * * \\
(12.892)\end{array}$ & $\begin{array}{c}-272.84 * * * \\
(13.625)\end{array}$ & $\begin{array}{c}-554.55^{* * *} * \\
(16.046)\end{array}$ \\
\hline Out of labor force & $\begin{array}{c}-477.67 * * * \\
(9.797)\end{array}$ & $\begin{array}{c}-394.13 * * * \\
(14.124)\end{array}$ & $\begin{array}{l}-478.25^{* * *} \\
(15.812)\end{array}$ \\
\hline Retired & $\begin{array}{c}-459.55 * * * \\
(18.254)\end{array}$ & $\begin{array}{c}-273.38 * * * \\
(24.372)\end{array}$ & $\begin{array}{c}-435.36 * * * \\
(28.260)\end{array}$ \\
\hline Number of children & $\begin{array}{l}128.09 * * * \\
(5.758)\end{array}$ & $\begin{array}{c}183.17 * * * \\
(9.570)\end{array}$ & $\begin{array}{l}109.47 * * * \\
\quad(6.684)\end{array}$ \\
\hline Female & $\begin{array}{c}-106.88 * * * \\
(15.572)\end{array}$ & $\begin{array}{c}-226.71 * * * \\
(14.182)\end{array}$ & $\begin{array}{c}-51.37 * * * \\
(18.952)\end{array}$ \\
\hline Male partner & $\begin{array}{c}1198.76^{* * *} \\
(12.173)\end{array}$ & - & - \\
\hline Female partner & $\begin{array}{l}908.05^{* * *} \\
(14.581)\end{array}$ & - & - \\
\hline Partner's years of education & - & - & $\begin{array}{c}107.84 * * * \\
(3.990)\end{array}$ \\
\hline Partner's age & - & - & $\begin{array}{c}29.32 * * * \\
\quad(4.693)\end{array}$ \\
\hline Partner's age squared & - & - & $\begin{array}{c}-0.25 * * * \\
(0.049)\end{array}$ \\
\hline Partner out of labor force & - & - & $\begin{array}{c}-432.54 * * * \\
(13.449)\end{array}$ \\
\hline Partner retired & - & - & $\begin{array}{c}-299.17 * * * \\
(26.368)\end{array}$ \\
\hline Constant & $\begin{array}{l}-1354.43^{* * * *} \\
\quad(55.798)\end{array}$ & $\begin{array}{c}462.19 * * * \\
(70.678)\end{array}$ & $\begin{array}{l}415.02 * * * \\
(104.386)\end{array}$ \\
\hline$N$ & 315,013 & 67,548 & 116,633 \\
\hline$R^{2}$ & 0.421 & 0.268 & 0.412 \\
\hline
\end{tabular}

Note: Standard errors in parentheses, clustered by households; both regressions include yearfixed effects (not explicitly reported); ${ }^{*} p<0.10,{ }^{* *} p<0.05$, ${ }^{* * *} p<0.01$. 


\section{The linear model}

The regressions results for the linear model are presented in Table 4. We follow Schwarze (2003) and estimate the linear model using an ordered logit model. ${ }^{9}$ As discussed in Section 3, the estimated coefficients on the logarithm of income, the logarithm of the number of household members and its interaction with the number of children can be used to derive the equivalence scale parameters $e_{a}$ and $b$. They combine to form the equivalence scale elasticity $e$, which is reported in the table's last row.

The first two columns represent variants of the model without reference income (equation (0)). In column 1, we do not take reference effects into account at all. In column 2, we follow the literature and linearly add a number of control variables. This reduces the estimated baseline elasticity from 0.492 to 0.381 . It also appears to cause a slightly larger downward adjustment when children are in the household, resulting in an even smaller equivalence scale elasticity for children. Even though the adjustment of the scale elasticity if children are present appears rather small, the difference becomes sizable when converting it into equivalence scales. For example, if a third person joins a two-person household, the household's equivalence weight rises by 22 percent if the third person is an adult, but only by 17 percent if it is a child. These estimates are relatively close to those found by Schwarze (2003, Table 3) in his pooled ordered logit analysis of SOEP data.

It should be noted that, even though some of the control variables in column 2 are also potential determinants of reference income, simply adding them as linear controls generally does not avoid the bias when estimating needs-based equivalence weights if income satisfaction is a composite of needs and status satisfaction. Instead, reference incomes have to be modeled explicitly in a way that allows them to vary with household composition.

In columns 3 to 5 of Table 4, we report results of estimating the linear version of equation (0), where we use the three underlying reference income specifications described in Section 6. In all three approaches, we obtain estimated coefficients of similar magnitudes. This corresponds to the observation that all the reference income measures are highly correlated (Appendix 2, Table A. 2). We find that for each definition of reference income, both absolute as well as relative household income have a strong, significantly positive effect on income satisfaction.

\footnotetext{
${ }^{9}$ Estimating the model using OLS gives qualitatively identical results.
} 
Table 4: Ordered logit regression results - linear specification

\begin{tabular}{|c|c|c|c|c|c|}
\hline \multirow[t]{3}{*}{ Dependent Variable: } & \multicolumn{5}{|c|}{ Satisfaction with household income } \\
\hline & (1) & $(2)$ & (3) & (4) & (5) \\
\hline & \multicolumn{2}{|c|}{ No reference effect } & Cell averages & Individual Mincer & Household Mincer \\
\hline In household income $\left(\beta_{1}\right)$ & $\begin{array}{c}2.016^{* * *} \\
(0.020)\end{array}$ & $\begin{array}{c}2.208 * * * \\
(0.022)\end{array}$ & $\begin{array}{c}1.548 * * * \\
(0.072)\end{array}$ & $\begin{array}{c}1.708 * * * \\
(0.027)\end{array}$ & $\begin{array}{c}1.678 * * * \\
(0.030)\end{array}$ \\
\hline ln household members $\left(\beta_{1} e_{a}\right)$ & $\begin{array}{c}-0.992 * * * \\
(0.030)\end{array}$ & $\begin{array}{c}-0.841 * * * \\
(0.030)\end{array}$ & $\begin{array}{c}-0.672 * * * \\
(0.073)\end{array}$ & $\begin{array}{c}-0.741^{* * *} \\
(0.035)\end{array}$ & $\begin{array}{c}-0.760 * * * \\
(0.034)\end{array}$ \\
\hline Children $* \ln$ household members $\left(\beta_{1} b\right)$ & $\begin{array}{c}0.040 * * * \\
(0.009)\end{array}$ & $\begin{array}{c}0.057 * * * \\
(0.009)\end{array}$ & $\begin{array}{r}-0.012 \\
(0.017)\end{array}$ & $\begin{array}{l}-0.002 \\
(0.010)\end{array}$ & $\begin{array}{l}0.000 \\
(0.010)\end{array}$ \\
\hline ln relative income & - & - & $\begin{array}{c}0.640 * * * \\
(0.069)\end{array}$ & $\begin{array}{c}0.504^{* * *} \\
(0.028)\end{array}$ & $\begin{array}{c}0.599 * * * \\
(0.036)\end{array}$ \\
\hline Age & - & $\begin{array}{c}-0.056 * * * \\
(0.003)\end{array}$ & - & - & - \\
\hline Age squared & - & $\begin{array}{c}0.001^{* * * *} \\
(0.000)\end{array}$ & - & - & - \\
\hline Female & - & $\begin{array}{c}0.152 * * * \\
(0.010)\end{array}$ & - & - & - \\
\hline Unemployed & - & $\begin{array}{c}-0.752 * * * \\
(0.024)\end{array}$ & - & - & - \\
\hline OLF & - & $\begin{array}{c}0.148 * * * \\
(0.017)\end{array}$ & - & - & - \\
\hline Retired & - & $\begin{array}{c}0.389 * * * \\
(0.030)\end{array}$ & - & - & - \\
\hline Years of education & - & $\begin{array}{l}-0.004 \\
(0.004)\end{array}$ & - & - & - \\
\hline East & - & $\begin{array}{c}-0.468 * * * \\
(0.022)\end{array}$ & - & - & - \\
\hline$N$ & 316,240 & 310,363 & 310,363 & 310,293 & 296,472 \\
\hline Pseudo $R^{2}$ & 0.054 & 0.073 & 0.055 & 0.055 & 0.055 \\
\hline$e_{a}=-\beta_{1} e_{a} / \beta_{1}$ & $\begin{array}{c}0.492 * * * \\
(0.013)\end{array}$ & $\begin{array}{c}0.381^{* * *} \\
(0.012)\end{array}$ & $\begin{array}{c}0.434^{* * *} \\
(0.034)\end{array}$ & $\begin{array}{c}0.434^{* * *} \\
(0.017)\end{array}$ & $\begin{array}{c}0.453^{* * *} \\
(0.017)\end{array}$ \\
\hline$b=\beta_{1} b / \beta_{1}$ & $\begin{array}{c}0.020 * * * \\
(0.005)\end{array}$ & $\begin{array}{c}0.026 * * * \\
(0.004)\end{array}$ & $\begin{array}{c}-0.008 \\
(0.011)\end{array}$ & $\begin{array}{r}-0.001 \\
(0.006)\end{array}$ & $\begin{array}{l}0.000 \\
(0.006)\end{array}$ \\
\hline$e=e_{a}-b k$ & $0.492-0.020 k$ & $0.381-0.026 k$ & $0.434+0.008 k$ & $0.434+0.001 k$ & $0.453-0.000 k$ \\
\hline
\end{tabular}

Note: Standard errors in parentheses, clustered by households in columns 1 and 2 and by reference groups in column 3; Column 4 and 5 report bootstrapped standard errors

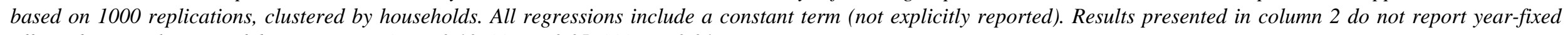
effects that are also part of the regression. ${ }^{*} p<0.10,{ }^{* *} p<0.05,{ }^{* * *} p<0.01$. 
A closer look at the implied equivalence scale parameters reveals changes that support our hypotheses. The weight attached to an additional adult is unambiguously lower than that suggested by a model ignoring reference effects entirely as in column 1 . Not controlling for reference income thus seems to overestimate an adults' equivalence weight. On the other hand, the deduction to be made for children becomes smaller and statistically insignificant when reference effects are being considered. Ignoring reference effects thus underestimates a child's equivalence weight relative to that of an adult. In fact, our results suggest that adults and children should receive approximately equal weights. It is also informative to compare these results with the model of column 2. Even though the set of control variables used in the model of column 2 and that used in the construction of reference income are nearly identical, the results differ substantially - in particular for children - because the model in column 2 cannot account for the differential impact of adults and children on needs and reference income. Following our theoretical reasoning, we therefore believe that the parameter estimates of columns 3 to 5 represent better approximations of needs-based equivalence scale parameters. They suggest practically equal changes in the equivalence scale when a partner or a child joins a household of a given size. In case that either of them is the second person in the household, their equivalence weight ranges between 35.1 to 36.9 percent. If they are the third person, their equivalence weight is between 26.0 and 27.6 percent.

\section{The nonlinear model}

We present the results of the nonlinear model in Table 5 . The equivalence weights are now estimated directly via nonlinear least squares and can be read off the first two rows of the table. In column 1, we again consider a model taking neither reference income nor comparison-relevant control variables into account. The equivalence weight of a partner adult is found to be about $35 \%$ of the first adult. The estimated equivalence weight of a child is estimated to be just about two thirds of that of the partner adult. This result changes substantially when further control variables are included in the regression. As can be seen in column 2, the equivalence weights of adults and children are both smaller than in column 1. Their magnitudes resemble those obtained by Biewen and Juhasz (2015). Most notably, we also find a large difference between the equivalence weights of additional adults and children. Children receive a weight of only 12 percent. 
Table 5: Nonlinear least squares regression results - nonlinear specification

\begin{tabular}{|c|c|c|c|c|c|}
\hline \multirow[t]{3}{*}{ Dependent variable: } & \multicolumn{5}{|c|}{ " Satisfaction with household income } \\
\hline & (1) & (2) & (3) & (4) & (5) \\
\hline & \multicolumn{2}{|c|}{ No reference effect } & Cell averages & Individual Mincer & Household Mincer \\
\hline Scale parameter adult & $\begin{array}{c}0.352 * * * \\
(0.015)\end{array}$ & $\begin{array}{c}0.301 * * * \\
(0.012)\end{array}$ & $\begin{array}{c}0.214^{* * *} \\
(0.051)\end{array}$ & $\begin{array}{c}0.240 * * * \\
(0.018)\end{array}$ & $\begin{array}{c}0.263^{* * *} \\
(0.019)\end{array}$ \\
\hline Scale parameter child & $\begin{array}{c}0.234 * * * \\
(0.009)\end{array}$ & $\begin{array}{c}0.120 * * * \\
(0.007)\end{array}$ & $\begin{array}{c}0.295 * * * \\
(0.027)\end{array}$ & $\begin{array}{c}0.262^{* * *} \\
(0.011)\end{array}$ & $\begin{array}{c}0.277 * * * \\
(0.012)\end{array}$ \\
\hline Equivalent income & $\begin{array}{c}2.268 * * * \\
(0.021)\end{array}$ & $\begin{array}{c}2.391 * * * \\
(0.023)\end{array}$ & $\begin{array}{c}1.570 * * * \\
(0.095)\end{array}$ & $\begin{array}{c}1.835^{* * *} \\
(0.030)\end{array}$ & $\begin{array}{c}1.798^{* * *} \\
(0.034)\end{array}$ \\
\hline Relative income & - & - & $\begin{array}{c}0.908 * * * \\
(0.092)\end{array}$ & $\begin{array}{c}0.654 * * * \\
(0.032)\end{array}$ & $\begin{array}{c}0.774^{* * * *} \\
(0.041)\end{array}$ \\
\hline Age & - & $\begin{array}{c}-0.059 * * * \\
(0.003)\end{array}$ & - & - & - \\
\hline Age squared & - & $\begin{array}{c}0.001 * * * \\
(0.000)\end{array}$ & - & - & - \\
\hline Female & - & $\begin{array}{c}0.141 * * * \\
(0.011)\end{array}$ & - & - & - \\
\hline Unemployment & - & $\begin{array}{c}-0.981 * * * \\
(0.028)\end{array}$ & - & - & - \\
\hline Out of labor force & - & $\begin{array}{c}0.140 * * * \\
(0.019)\end{array}$ & - & - & - \\
\hline Retired & - & $\begin{array}{c}0.429 * * * \\
(0.031)\end{array}$ & - & - & - \\
\hline Years of education & - & $\begin{array}{c}-0.011 * * * \\
(0.004)\end{array}$ & - & - & - \\
\hline East & - & $\begin{array}{c}-0.507 * * * \\
(0.025) \\
\end{array}$ & - & - & - \\
\hline$N$ & 316,240 & 310,363 & 310,363 & 310,293 & 296,472 \\
\hline $\operatorname{adj} . R^{2}$ & 0.204 & 0.269 & 0.208 & 0.209 & 0.209 \\
\hline
\end{tabular}

Note: Standard errors in parentheses, clustered by households in columns 1 and 2 and by reference groups in column 3; Column 4 and 5 report bootstrapped standard errors

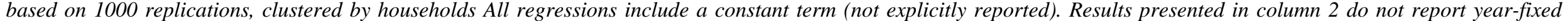
effects that are also part of the regression. $* p<0.10, * * p<0.05, * * * p<0.01$. 
This finding is reversed when reference incomes are incorporated explicitly. The findings of estimating the nonlinear version of equation (0) are reported in columns 3 to 5 . Although reference incomes are differently constructed in the three columns, the results are very similar. As in the linear model, the household's absolute equivalent income as well as relative household income have a strong and positive relation with income satisfaction. Compared to columns 1 and 2, the equivalence weight of an additional adult decreases whereas the weight of a child strongly increases. Indeed, children are assigned a slightly greater weight in all three approaches. The estimated weights of additional adults and children are all in the range of 20 to 30 percent. This confirms our hypotheses that ignoring reference income effects overestimates adults’ needs while it underestimates the needs of children.

\section{Robustness Tests}

We now examine whether our main result - adults and children receive similar equivalence weights when we take reference effects into account - is robust to changes in our model's specification. Due to the convenience of having equivalence weights estimated directly, we present the results only for the nonlinear framework. Conducting these tests in the linear framework yields similar results.

The results of four robustness tests are presented in Table 6. The first column presents a model where, in the "cell average approach", relative income is replaced by the percentile rank within the reference group's income distribution, which was found to have an impact on satisfaction by Clark et al. (2009) and Boyce et al. (2010). The regression results suggest that income satisfaction increases as the rank within the reference income distribution rises and thus also support the claim that relative income positions matter. The change in the definition of the reference effect results in a slight increase in the equivalence weight of adults and a slight decrease in the weight of children (compared to Table 5, column 3). Hence, the difference in both parameters becomes smaller.

One could be worried that the nonlinear least squares results suffer from having to assume cardinality of the income satisfaction data. To take into account the ordinal nature of the dependent variable also in the nonlinear model, we carry out a probit-adjustment before running the nonlinear least squares regression (van Praag and Ferrer-i-Carbonell, 2004). As 
can be seen in column 2, the estimated equivalence weights are larger than those derived in Table 5, column 5, but stay very close to each other. ${ }^{10}$

Table 6: Robustness tests

\begin{tabular}{|c|c|c|c|c|}
\hline \multirow[t]{3}{*}{ Dependent variable: } & \multicolumn{4}{|c|}{ Satisfaction with household income } \\
\hline & (1) & $(2)$ & $(3)$ & (4) \\
\hline & $\begin{array}{c}\text { Percentile rank } \\
\text { within reference } \\
\text { group }\end{array}$ & Probit-adjusted & $\begin{array}{l}\text { Including mean } \\
\text { relative income }\end{array}$ & $\begin{array}{l}\text { No households } \\
\text { with payments } \\
\text { to children } \\
\text { outside } \\
\end{array}$ \\
\hline Scale parameter adult & $\begin{array}{c}0.224 * * * \\
(0.044)\end{array}$ & $\begin{array}{c}0.290 * * * \\
(0.019)\end{array}$ & $\begin{array}{c}0.258 * * * \\
(0.019)\end{array}$ & $\begin{array}{c}0.263 * * * \\
(0.019)\end{array}$ \\
\hline Scale parameter child & $\begin{array}{c}0.277 * * * \\
(0.022)\end{array}$ & $\begin{array}{c}0.292 * * * \\
(0.013)\end{array}$ & $\begin{array}{c}0.280 * * * \\
(0.012)\end{array}$ & $\begin{array}{c}0.263 * * * \\
(0.012)\end{array}$ \\
\hline Equivalent income & $\begin{array}{c}1.687 * * * \\
(0.067)\end{array}$ & $\begin{array}{c}0.764 * * * \\
(0.015)\end{array}$ & $\begin{array}{c}1.781 * * * \\
(0.035)\end{array}$ & $\begin{array}{c}1.828 * * * \\
(0.037)\end{array}$ \\
\hline Relative income & - & $\begin{array}{c}0.328 * * * \\
(0.019)\end{array}$ & $\begin{array}{c}0.449 * * * \\
(0.041)\end{array}$ & $\begin{array}{c}0.774 * * * \\
(0.045)\end{array}$ \\
\hline Percentile rank & $\begin{array}{c}0.011 * * * \\
(0.001)\end{array}$ & - & - & - \\
\hline Mean relative income & - & - & $\begin{array}{c}0.518 * * * \\
(0.045)\end{array}$ & - \\
\hline $\begin{array}{l}N \\
\text { adj. } R^{2} \\
\end{array}$ & $\begin{array}{c}310,303 \\
0.209 \\
\end{array}$ & $\begin{array}{c}296,472 \\
0.203 \\
\end{array}$ & $\begin{array}{c}296,472 \\
0.211 \\
\end{array}$ & $\begin{array}{c}267,581 \\
0.209 \\
\end{array}$ \\
\hline
\end{tabular}

Note: Standard errors in parentheses. Column 1 uses the cell average approach; columns 2-4 employ the household Mincer approach. Standard errors clustered by reference groups in column 1, bootstrapped with 1000 replications and clustered by households in columns 2-4. All regressions also include a constant term (not explicitly reported); ${ }^{*} p<0.10,{ }^{* *} p<0.05,{ }^{* * *} p<$ 0.01 .

Changes in one's income relative to some reference group might have very different effects, depending on whether this change is perceived as temporary or permanent. A simple, albeit only approximate way to distinguish between temporary and permanent effects is to simultaneously control for an individuals' relative income and for the time-mean of this person's relative income while in the panel (van Praag et al., 2003). We find that the timeinvariant mean relative income as well as temporary deviations from it positively affect income satisfaction (column 3). The estimated equivalence scale parameters, however, change only very little.

\footnotetext{
${ }^{10}$ Since the "household Mincer" is our most preferred approach to estimate reference incomes, we present the results of the following robustness checks for this approach only. The other approaches yield similar results.
} 
One matter of concern could be that our sample includes some individuals that make payments to children outside of their own household. These payments may be voluntary or due to legal obligations, but they do mean that household income is shared among more individuals than those captured by our specification of the equivalence scale. We address this problem by excluding all households that make payments to children outside of it. This sample restriction implies a loss of 28,891 observations, but changes estimates very little (column 4). The equivalence scale parameter for children is slightly reduced, which closes the gap between children's and adults' equivalence weights.

\section{Extensions}

There are a number of extensions to our baseline model that help us to further evaluate the robustness of our results while giving some valuable insights into household economies of scale and reference income effects. For the sake of brevity, we discuss only the results from the household Mincer approach in the nonlinear model. One common extension in the literature concerns the age structure of children in the household. We differentiate between three groups: children that are 0 to 5 years, 6 to 13 years, and 14 to 17 years old. We estimate equivalence scale parameters for each of these groups by incorporating them separately into our specification of equivalent income. The results of this extension are shown in Column 1 of Table 7. The estimated equivalence scale parameters differ between children of different ages. Material needs seem to be relatively low for very young children and tend to increase with a child's age. While the equivalence parameter for children aged 6 to 13 years is only slightly higher than that of younger children, the weight of a child belonging to the oldest group appears to be strikingly high. It exceeds the parameter for a partner considerably, thus suggesting personal material needs of a teenager to be large. This implies that households with teenagers enjoy considerably lower economies of scales than with partners or younger children.

We now add more flexibility to the functional relationship between reference income and income satisfaction. Firstly, we allow for asymmetric reference effects by interacting relative income with a dummy variable that indicates whether the household's income is above or below its reference value as in Ferrer-i-Carbonell (2005). The results in column 2 suggest that a higher relative income has positive effects on satisfaction for both, individuals with 
household income above and below the reference point. However, the positive effect is much stronger in the latter case. Hence, relatively rich individuals seem to gain much less additional income satisfaction from getting richer than do individuals that are relatively poor. Nevertheless, the estimated equivalence weights are still very similar to our previous results.

Table 7: Extended model specifications

\begin{tabular}{|c|c|c|c|}
\hline \multirow[t]{2}{*}{ Dependent variable: } & \multicolumn{3}{|c|}{ Satisfaction with household income } \\
\hline & (1) & $(2)$ & (3) \\
\hline & $\begin{array}{l}\text { Age-dependent } \\
\text { parameters }\end{array}$ & $\begin{array}{c}\text { Asymmetric reference } \\
\text { effect }\end{array}$ & $\begin{array}{c}\text { Reference effect } \\
\text { depending on family } \\
\text { structure }\end{array}$ \\
\hline Scale parameter adult & $\begin{array}{c}0.270^{* * * *} \\
(0.019)\end{array}$ & $\begin{array}{c}0.278 * * * \\
(0.019)\end{array}$ & $\begin{array}{c}0.278 * * * \\
\quad(0.018)\end{array}$ \\
\hline Scale parameter child 0-5 & $\begin{array}{c}0.227 * * * \\
(0.016)\end{array}$ & - & - \\
\hline Scale parameter child 6-13 & $\begin{array}{c}0.253^{* * *} \\
(0.014)\end{array}$ & - & - \\
\hline Scale parameter child 14-17 & $\begin{array}{c}0.414^{* * *} \\
(0.019)\end{array}$ & - & - \\
\hline Scale parameter child & - & $\begin{array}{c}0.291^{* * * *} \\
(0.012)\end{array}$ & $\begin{array}{c}0.279 * * * \\
(0.012)\end{array}$ \\
\hline Equivalent income & $\begin{array}{c}1.816^{* * *} \\
(0.035)\end{array}$ & $\begin{array}{c}1.798 * * * \\
(0.035)\end{array}$ & $\begin{array}{c}1.799 * * * \\
(0.034)\end{array}$ \\
\hline Relative income & $\begin{array}{c}0.756^{* * *} \\
(0.044)\end{array}$ & - & - \\
\hline Above reference income & - & $\begin{array}{c}0.156^{* * * *} \\
(0.056)\end{array}$ & - \\
\hline Below reference income & - & $\begin{array}{c}1.187 * * * \\
(0.055)\end{array}$ & - \\
\hline One-adult relative income & - & - & $\begin{array}{c}0.991 * * * \\
(0.053)\end{array}$ \\
\hline Two-adult relative income & - & - & $\begin{array}{c}0.683 * * * \\
(0.046)\end{array}$ \\
\hline$N$ & 296,472 & 296,472 & 296,472 \\
\hline adj. $R^{2}$ & 0.210 & 0.212 & 0.210 \\
\hline
\end{tabular}

Note: Standard errors in parentheses, bootstrapped with 1000 replications and clustered by households. All regressions also include a constant term (not explicitly reported). ${ }^{*} p<0.10,{ }^{* *} p<0.05,{ }^{* * *} p<0.01$.

In a second adjustment to increase flexibility of the reference effect, we allow the reference income effect to vary with the number of adults living within a household. We estimate coefficients reflecting the reference effect separately by interacting relative income with a dummy variable indicating the number of adults in the household. We are thus able to investigate whether individuals living in single and couple households systematically differ from each other in the sense of how much importance they assign to their relative household income. The results of this extension, presented in column 3, indeed indicate such a difference. It can be seen that the relative income effect is considerably greater for singles 
than for individuals living in couple households. This could either be interpreted as evidence for our reference income measure being less precise when the number of adults increases, or it could reflect the problem that personal success also matters for income satisfaction. An adult living in a partnership may derive less satisfaction from an increase in household income than a single, because it may not be directly attributed to her but to her partner's increased earnings. One might also claim that individuals living in a partnership simply do not care as much about relative income positions as singles do. No matter what the exact reason is, it can be seen that, although there is a difference in relative income effects, the equivalence weights do not change significantly.

\section{Conclusion}

In this study, we have illustrated that equivalence scales derived from data on income satisfaction may capture effects that go beyond differences in needs. Neglecting the separate identification of these effects generally causes biased estimates of equivalence weights. More specifically, we have provided evidence that income satisfaction depends only partly on the degree to which needs are satisfied, and that social comparisons are another determinant of income satisfaction. If family size influences not only a household's needs, but also its reference group, the estimation of a purely needs-based equivalence scale requires taking reference effects explicitly into account. Previous studies, which did not control for relative income, typically obtained much smaller equivalence weights for children than for additional adults. Our results suggest that this difference arises because children affect a household's needs in a similar way as additional adults, but have only a small effect on the household's reference income. We propose a model that explicitly separates the two effects. We obtain lower equivalence weights for adults and higher weights for children, such that, overall, we do not find significant differences in the equivalence weights of adults and children anymore. Across all our estimations, additional adults and children receive similar weights of 30 to 40 percent in the linear and 20 to 30 percent in the nonlinear model.

We do not want to suggest that previous attempts to recover equivalence scales from subjective data have been flawed, per se. As Coulter et al. (1992) already argued, there is no universally applicable equivalence scale, because which scale is "true" is ultimately a normative judgment about which effects should, or should not, be considered. In this study, 
we intend to raise awareness that what estimated equivalence scales actually measure might not be what they were meant to measure. One can say that previous studies determined the compensation needed to keep income satisfaction constant across household structures. However, since income satisfaction seems to be determined not only by needs fulfillment, but also by income comparisons with others and status considerations, it is debatable whether all these effects should be seen as welfare-relevant and should thus affect the equivalence scale. This is ultimately a normative question that our analysis cannot answer. We show, however, how the purely needs-based part of income satisfaction can be separated from its incomecomparison part. If one is interested in the necessary incomes that allow families of different sizes to achieve the same level of needs fulfillment, and one is willing to accept that this does not necessarily imply that income satisfaction is equalized across households, our estimates might be a better guide than those of previous studies.

Having included reference incomes, the large difference between adults and children found in other studies disappears and both groups receive equivalence weights of around 30 percent. This resembles the weight that the modified OECD scale assigns to children. The estimated weight of adults, however, is lower than suggested by the OECD scale. This may be due to our focus on partner adults only. If we include other adults who are not partners, we would obtain a scale where adults, once again, receive higher weights than children.

Further research is required to deepen our understanding of the reference effects assessed in this paper and to investigate reference effects in the evaluation of satisfaction with household income in general. A crucial aspect is the determination of the correct reference group. It may be possible, too, that income comparisons are carried out on a number of different levels, e.g. neighbors, colleagues, or family members, which could have implications for the equivalence scale estimates. Apart from interpersonal comparisons, it may also be relevant to consider intertemporal comparisons with oneself to see if expectations or the adaptation to household arrangements or incomes are important factors in the evaluation of household income. Taking such aspects into account as well as investigating other channels through which income satisfaction may be affected, could help to understand even better what is actually being measured by equivalence scales derived from income satisfaction data. Given a normative agreement on what an equivalence scale should capture, a better understanding of what determines income satisfaction will be helpful for determining even more precise estimates of equivalence weights. 


\section{References}

BBSR (2009). Regionaler Preisindex. Berichte, Band 30, Bundesinstitut für Bau-, Stadt- und Raumforschung, Bonn.

Biewen, M. and A. Juhasz (2015). Direct Estimation of Equivalence Scales, Paper presented at the 29th Annual Conference of the European Society for Population Economics, June 2015, Izmir; revised version of: M. Biewen and A. Juhasz, A Goodness-of-Fit Approach to Estimating Equivalence Scales, IZA Discussion Paper No. 7109, 2013, Bonn: IZA.

Bollinger, C., C. Nicoletti, and S. Pudney (2012). Two Can Live as Cheaply as One... But Three's a Crowd. Discussion Papers in Economics, No. 12/23, The University of York.

Boyce, C. J., G. D. Brown and S. C. Moore (2010). Money and Happiness: Rank of Income, not Income, Affects Life Satisfaction. Psychological Science, 21(4), 471-475.

Bradbury, B. (1989). Family Size Equivalence Scales and Survey Evaluations of Income and Well-Being. Journal of Social Policy, 18(03), 383-408.

Buhmann, B., L. Rainwater, G. Schmaus and T. M. Smeeding (1988). Equivalence Scales, Well-Being, Inequality, and Poverty: Sensitivity Estimates across Ten Countries Using the Luxembourg Income Study (LIS) Database. Review of Income and Wealth, 34(2), $115-142$

Charlier, E. (2002). Equivalence Scales in an Intertemporal Setting with an Application to the Former West Germany. Review of Income and Wealth, 48(1), 99-126.

Clark, A. E., P. Frijters, and M. A. Shields (2008). Relative Income, Happiness, and Utility: An explanation for the Easterlin Paradox and other Puzzles. Journal of Economic literature, 46(1), 95-144.

Clark, A. E., and A. J. Oswald (1996). Satisfaction and comparison income. Journal of Public Economics 61(3), 359-381.

Clark, A. E. and C. Senik (2010). Who Compares to Whom? The Anatomy of Income Comparisons in Europe. The Economic Journal, 120(544), 573-594.

Clark, A. E., N. Westergård-Nielsen and N. Kristensen (2009). Economic Satisfaction and Income Rank in Small Neighbourhoods. Journal of the European Economic Association, 7(2-3), 519-527.

Coulter, F. A., F. A. Cowell, and S. P. Jenkins S. P. (1992). Differences in needs and assessment of income distributions. Bulletin of Economic Research, 44(2), 77-124.

Deaton, A. S., and J. Muellbauer (1986). On Measuring Child Costs: With Applications to Poor Countries. The Journal of Political Economy, 94(4), 720-744.

Ferrer-i-Carbonell, A. (2005). Income and Well-Being: An Empirical Analysis of the Comparison Income Effect. Journal of Public Economics, 89(5), 997-1019.

FitzRoy, F. R., M. A. Nolan, M. F. Steinhardt and D. Ulph (2014). Testing the Tunnel Effect: Comparison, Age and Happiness in UK and German Panels. IZA Journal of European Labor Studies, 3(24).

Goedhart, T., V. Halberstadt, A. Kapteyn, and B. M. S. van Praag (1977). The Poverty Line: Concept and Measurement. The Journal of Human Resources, 12, 503-520. 
Goerke, L. and M. Pannenberg (2015). Direct Evidence on Income Comparisons and Subjective Well-Being Across Income Groups, Economics Letters, 137, 95-101.

Lewbel, A., and K. Pendakur (2008). Equivalence scales. New Palgrave Dictionary of Economics.

McBride, M. (2001). Relative-income effects on subjective well-being in the cross-section. Journal of Economic Behavior \& Organization, 45(3), 251-278.

McClements, L. D. (1977). Equivalence scales for children. Journal of Public Economics, 8(2), 191-210.

Melenberg, B. and A. van Soest (1996). Measuring the Costs of Children: Parametric and Semiparametric Estimators. Statistica Neerlandica, 50(1), 171-192.

Mujcic, R. and P. Frijters (2015). Conspicuous Consumption, Conspicuous Health, and Optimal Taxation. Journal of Economic Behavior \& Organization, 111, 59-70.

OECD (2005). What are equivalence scales?, available at http://www.oecd.org/eco/growth/OECD-Note-EquivalenceScales.pdf.

Pollak, R. A. and T. J. Wales (1979). Welfare Comparisons and Equivalence Scales. The American Economic Review, 69, 216-221.

Rojas, M. (2007). A Subjective Well-Being Equivalence Scale for Mexico: Estimation and Poverty and Income-Distribution Implications. Oxford Development Studies, 35(3), 273293.

Schwarze, J. (2003). Using Panel Data on Income Satisfaction to Estimate Equivalence Scale Elasticity. Review of Income and Wealth, 49(3), 359-372.

Senik, C. (2008). Ambition and Jealousy: Income Interactions in the 'Old'Europe versus the 'New'Europe and the United States. Economica, 75(299), 495-513.

Steiger, D. M., Mainieri, T., \& Stinson, L. (1997). Subjective assessments of economic wellbeing: Understanding the minimum income question. In the Proceedings of the Joint Statistical Meetings Section on Survey Research Methods. American Statistical Association, Alexandria, VA, 899-903.

Stutzer, A. (2004). The Role of Income Aspirations in Individual Happiness. Journal of Economic Behavior \& Organization, 54(1), 89-109.

Van Praag, B. M. S. (1971). The Welfare Function of Income in Belgium: An Empirical Investigation. European Economic Review, 2(3), 337-369.

Van Praag, B. M. S., Frijters, P., \& Ferrer-i-Carbonell, A. (2003). The anatomy of subjective well-being. Journal of Economic Behavior \& Organization, 51(1), 29-49.

Van Praag, B. M. S. and A. Ferrer-i-Carbonell (2004). Happiness Quantified: A Satisfaction Calculus Approach. Oxford: Oxford University Press.

Van Praag, B. M. S. and N. L. van der Sar (1988). Household Cost Functions and Equivalence Scales. Journal of Human Resources, 23, 193-210.

Van Praag, B. M. and M. F. Warnaar (1997). The Cost of Children and the Use of Demographic Variables in Consumer Demand. Handbook of population and family economics, 1, 241-273. 
Wagner, G. G., J. R. Frick and J. Schupp (2007). The German Socio-Economic Panel Study (SOEP) - Scope, Evolution and Enhancements. Schmollers Jahrbuch, 127(1), 139-169. 


\section{Appendix 1: The role of relative income. Formal analysis for the nonlinear model}

A similar reasoning to the one presented in Section 3.3 can be used to illustrate the bias when neglecting reference effects in the nonlinear model. Assume for illustrative purposes that equation (0) can be extended to include reference effects in the following way:

$$
\begin{gathered}
S_{i t}=\alpha+\beta_{1} \ln \left(\frac{Y_{i t}}{1+\delta_{a 1}\left(a_{i t}-1\right)+\delta_{k 1} k_{i t}}\right)+\beta_{2} \ln \left(\frac{Y_{i t}}{\omega\left(1+\delta_{a 2}\left(a_{i t}-1\right)+\delta_{k 2} k_{i t}\right)}\right)+\varepsilon_{i t} \\
=\alpha-\beta_{2} \ln \omega+\left(\beta_{1}+\beta_{2}\right) \ln Y_{i t}-\beta_{1} \ln \left(1+\delta_{a 1}\left(a_{i t}-1\right)+\delta_{k 1} k_{i t}\right) \\
-\beta_{2} \ln \left(1+\delta_{a 2}\left(a_{i t}-1\right)+\delta_{k 2} k_{i t}\right)+\varepsilon_{i t}
\end{gathered}
$$

Linearizing this equation's nonlinear components, using a Taylor approximation around $\left(a_{i t}=a_{0}, k_{i t}=k_{0}\right)$, gives

$$
\begin{gathered}
S_{i t} \approx \alpha-\beta_{2} \ln \omega+\left(\beta_{1}+\beta_{2}\right) \ln Y_{i t} \\
-\beta_{1} \frac{\delta_{a 1}}{1+\delta_{a 1}\left(a_{0}-1\right)+\delta_{k 1} k_{0}}\left(a_{i t}-a_{0}\right) \\
-\beta_{1} \frac{\delta_{k 1}}{1+\delta_{a 1}\left(a_{0}-1\right)+\delta_{k 1} k_{0}}\left(k_{i t}-k_{0}\right) \\
-\beta_{2} \frac{\delta_{a 2}}{1+\delta_{a 2}\left(a_{0}-1\right)+\delta_{k 2} k_{0}}\left(a_{i t}-a_{0}\right) \\
-\beta_{2} \frac{\delta_{k 2}}{1+\delta_{a 2}\left(a_{0}-1\right)+\delta_{k 2} k_{0}}\left(k_{i t}-k_{0}\right)+\varepsilon_{i t}
\end{gathered}
$$

Regrouping terms yields

$$
\begin{aligned}
S_{i t} \approx & -\beta_{2} \ln \omega+\left(\begin{array}{c}
\beta_{1} \frac{\delta_{a 1}}{1+\delta_{a 1}\left(a_{0}-1\right)+\delta_{k 1} k_{0}} \\
\left.+\beta_{2} \frac{\delta_{a 2}}{1+\delta_{a 2}\left(a_{0}-1\right)+\delta_{k 2} k_{0}}\right)
\end{array}\right) a_{0}+\left(\begin{array}{c}
\beta_{1} \frac{\delta_{k 1}}{1+\delta_{a 1}\left(a_{0}-1\right)+\delta_{k 1} k_{0}} \\
\left.+\beta_{2} \frac{\delta_{k 2}}{1+\delta_{a 2}\left(a_{0}-1\right)+\delta_{k 2} k_{0}}\right)
\end{array}\right) k_{0} \\
& +\left(\beta_{1}+\beta_{2}\right) \ln Y_{i t}-\left(\beta_{1} \frac{\delta_{a 1}}{1+\delta_{a 1}\left(a_{0}-1\right)+\delta_{k 1} k_{0}}+\beta_{2} \frac{\delta_{a 2}}{1+\delta_{a 2}\left(a_{0}-1\right)+\delta_{k 2} k_{0}}\right) a_{i t} \\
& +\left(\beta_{1} \frac{\delta_{k 1}}{1+\delta_{a 1}\left(a_{0}-1\right)+\delta_{k 1} k_{0}}+\beta_{2} \frac{\delta_{k 2}}{1+\delta_{a 2}\left(a_{0}-1\right)+\delta_{k 2} k_{0}}\right) k_{i t}+\varepsilon_{i t}
\end{aligned}
$$


Analogously linearizing (0), indicating the respective estimates with a tilde, and comparing the result with (0) yields

$$
\begin{aligned}
& \frac{\tilde{\delta}_{a}}{1+\tilde{\delta}_{a}\left(a_{0}-1\right)+\tilde{\delta}_{k} k_{0}}=\frac{\beta_{1}}{\beta_{1}+\beta_{2}} \frac{\delta_{a 1}}{1+\delta_{a 1}\left(a_{0}-1\right)+\delta_{k 1} k_{0}}+\frac{\beta_{2}}{\beta_{1}+\beta_{2}} \frac{\delta_{a 2}}{1+\delta_{a 2}\left(a_{0}-1\right)+\delta_{k 2} k_{0}} \\
& \frac{\tilde{\delta}_{k}}{1+\tilde{\delta}_{a}\left(a_{0}-1\right)+\tilde{\delta}_{k} k_{0}}=\frac{\beta_{1}}{\beta_{1}+\beta_{2}} \frac{\delta_{k 1}}{1+\delta_{a 1}\left(a_{0}-1\right)+\delta_{k 1} k_{0}}+\frac{\beta_{2}}{\beta_{1}+\beta_{2}} \frac{\delta_{k 2}}{1+\delta_{a 2}\left(a_{0}-1\right)+\delta_{k 2} k_{0}}
\end{aligned}
$$

Solving this for $\tilde{\delta}_{a}$ and $\tilde{\delta}_{k}$ gives

$$
\tilde{\delta}_{i}=\frac{\beta_{2} \delta_{i 2}\left(1+\delta_{a 1}\left(a_{0}-1\right)+\delta_{k 1} k_{0}\right)+\beta_{1} \delta_{i 1}\left(1+\delta_{a 2}\left(a_{0}-1\right)+\delta_{k 2} k_{0}\right)}{\beta_{2}\left(1+\delta_{a 1}\left(a_{0}-1\right)+\delta_{k 1} k_{0}\right)+\beta_{1}\left(1+\delta_{a 2}\left(a_{0}-1\right)+\delta_{k 2} k_{0}\right)}, \quad i=\{a, k\}
$$

To illustrate the bias, it suffices to show that $\tilde{\delta}_{i}$ is always between $\delta_{i 1}$ and $\delta_{i 2}$, for $i=\{a, k\}$. This is true if $\left(\delta_{i 1}-\tilde{\delta}_{i}\right)\left(\delta_{i 2}-\tilde{\delta}_{i}\right) \leq 0$. Using (0), one obtains

$$
\begin{aligned}
\left(\delta_{i 1}-\tilde{\delta}_{i}\right) & \left(\delta_{i 2}-\tilde{\delta}_{i}\right) \\
& =-\frac{\beta_{1} \beta_{2}\left(\delta_{i 1}-\delta_{i 2}\right)^{2}\left(1+\delta_{a 1}\left(a_{0}-1\right)+\delta_{k 1} k_{0}\right)\left(1+\delta_{a 2}\left(a_{0}-1\right)+\delta_{k 2} k_{0}\right)}{\left[\beta_{2}\left(1+\delta_{a 1}\left(a_{0}-1\right)+\delta_{k 1} k_{0}\right)+\beta_{1}\left(1+\delta_{a 2}\left(a_{0}-1\right)+\delta_{k 2} k_{0}\right)\right]^{2}} \leq 0,
\end{aligned}
$$

for $i=\{a, k\}$. Hence, neglecting reference income effects in the determination of income satisfaction causes an overestimation (underestimation) of the purely needs-based equivalence weight of household members if their weight in the determination of reference income is larger (less) than their weight in the needs-based household equivalence weight. 


\section{Appendix 2: Additional tables}

Table A. 1 Mean values of important control variables by household type

\begin{tabular}{|c|c|c|c|c|c|c|c|c|}
\hline \multirow{2}{*}{\multicolumn{2}{|c|}{$\begin{array}{c}\text { Composition of } \\
\text { household }\end{array}$}} & \multicolumn{7}{|c|}{ "Sample Means } \\
\hline & & Age & $\begin{array}{c}\text { Education } \\
\text { level }\end{array}$ & East & OLF & Retired & Employed & $\begin{array}{c}\text { Un- } \\
\text { employed }\end{array}$ \\
\hline \multirow{8}{*}{1 adult } & No children & 56.82 & 11.63 & 0.15 & 0.11 & 0.40 & 0.44 & 0.04 \\
\hline & & (20.31) & $(2.56)$ & $(0.35)$ & $(0.32)$ & $(0.49)$ & $(0.50)$ & $(0.20)$ \\
\hline & 1 child & 37.74 & 11.70 & 0.20 & 0.17 & 0.01 & 0.68 & 0.14 \\
\hline & & (9.15) & $(2.36)$ & $(0.40)$ & $(0.38)$ & $(0.09)$ & $(0.47)$ & $(0.35)$ \\
\hline & 2 children & 36.80 & 11.69 & 0.17 & 0.21 & 0.00 & 0.67 & 0.12 \\
\hline & & (6.66) & (2.49) & $(0.37)$ & $(0.41)$ & $(0.03)$ & $(0.47)$ & $(0.33)$ \\
\hline & 3 children & 36.53 & 11.57 & 0.17 & 0.31 & 0.00 & 0.47 & 0.22 \\
\hline & & (5.26) & $(2.84)$ & $(0.38)$ & $(0.46)$ & $(0.00)$ & $(0.50)$ & $(0.42)$ \\
\hline \multirow{8}{*}{$\begin{array}{l}2 \\
\text { adults }\end{array}$} & No children & 56.61 & 11.53 & 0.17 & 0.19 & 0.32 & 0.45 & 0.04 \\
\hline & & $(16.31)$ & $(2.41)$ & $(0.37)$ & $(0.39)$ & $(0.47)$ & $(0.50)$ & $(0.19)$ \\
\hline & 1 child & 37.03 & 11.92 & 0.17 & 0.20 & 0.00 & 0.74 & 0.05 \\
\hline & & (8.76) & $(2.43)$ & $(0.37)$ & $(0.40)$ & $(0.05)$ & $(0.44)$ & $(0.22)$ \\
\hline & 2 children & 37.26 & 12.09 & 0.14 & 0.21 & 0.00 & 0.75 & 0.04 \\
\hline & & $(6.27)$ & (2.58) & $(0.35)$ & $(0.41)$ & $(0.02)$ & $(0.43)$ & $(0.20)$ \\
\hline & 3 children & 37.31 & 11.82 & 0.11 & 0.28 & 0.00 & 0.67 & 0.06 \\
\hline & & (5.88) & $(2.78)$ & $(0.31)$ & $(0.45)$ & $(0.00)$ & $(0.47)$ & $(0.23)$ \\
\hline
\end{tabular}

Source: SOEP, own calculations, using weights; Note: Standard deviation in parentheses.

Table A. 2 Correlation between differently constructed reference income measures

\begin{tabular}{lccc}
\hline \hline & Cell average approach & $\begin{array}{c}\text { Individual Mincer } \\
\text { approach }\end{array}$ & $\begin{array}{c}\text { Household Mincer } \\
\text { approach }\end{array}$ \\
\hline $\begin{array}{l}\text { Cell average approach } \\
\begin{array}{l}\text { Individual Mincer } \\
\text { approach }\end{array}\end{array}$ & 1.000 & 1.0000 \\
$\begin{array}{l}\text { Household Mincer } \\
\text { approach }\end{array}$ & $0.855^{* * *}$ & $0.926^{* * *}$ & 1.0000 \\
\hline \hline
\end{tabular}

Source: SOEP, own calculations. ${ }^{*} p<0.10,{ }^{* *} p<0.05,{ }^{* * *} p<0.01$ 


\section{Appendix 3: Construction of regional price indices}

Unfortunately, the German Statistical Office does not regularly report information on price level differences between East and West Germany. Hence, we have to construct such indices using alternative sources. We use the price level index of each German administrative district in 2007, reported by the BBSR (2009), and weight it with the respective districts' population in 2007 (German Statistical Office, 2015) to obtain average price levels of East and West Germany, respectively. Despite its divided history and geographical location, Berlin has been assigned to West Germany in our construction of regional aggregates. The corresponding indices suggest that the price level in East Germany was about $7 \%$ lower than in West Germany in 2007.

We calculate regional price levels in the years before and after 2007 by adjusting the 2007 figures using regional inflation rates. A dataset published by the German Statistical Office differentiates changes in annual consumer price indices between East and West Germany (but not their levels). These data are available from the beginning of our sampling period, 1984, but have not been released after 1999. Therefore, we need to complete the time series by aggregating state-level data that is available for all years after 1995. Unfortunately, two out of 16 German states, more specifically the West-German states Hamburg and SchleswigHolstein, do not report their own consumer price index. Bremen, another West-German state, has started to do so only in 2005. Consequently, we assume that those states experienced inflation rates corresponding to the other West-German states' average. Considering these limitations, we construct our time-series of consumer prices for East and West Germany as follows: We use regional data from 1984 to 1995, where the index for East Germany in 1990 is calculated by the average of the year's last six months. From 1995 onwards, price indices released by the single states are aggregated into annual average values for East and West based on weights of the states' population in each year. The price indices determined on the basis of state-specific data are very similar to the aggregate data available until 1999, thus confirming the accuracy of our constructed measure. Finally, all index values are set in relation to the base year 2007 . 